\title{
PARENTS' INVOLVEMENT IN LEARNING ASSESSMENT DURING REMOTE LEARNING IN PANDEMIC ERA
}

\author{
Haiyudi ${ }^{1}$, Sitthipon Art-in ${ }^{2}$ \\ 1Master of Education Program in Curriculum and Instruction, Faculty of Education, Khon Kaen University, \\ Thailand \\ 2Associate Professor in Curriculum and Instruction Program, Faculty of Education, Khon Kaen University, \\ Thailand \\ haiyudi@gmail.com
}

Article History

Received: 30 Agustus 2020, Accepted:7 Januari 2021, Published: 26 Februari 2021

\begin{abstract}
Abstrak
Penelitian ini bertujuan untuk memberikan skema penilaian baru selama pembelajaran jarak jauh (PJJ) dengan melibatkan orang tua. Peran guru dan orang tua dalam komunikasi intensif sangat ditekankan untuk meningkatkan hasil prestasi siswa. Metode yang digunakan dalam penelitian ini adalah kajian pustaka argumentatif terhadap dokumen Panduan Penilaian oleh Pendidik dan Satuan Pendidikan oleh Kemendikbud (2017). Kajian ini bertujuan untuk mengurangi beban kerja guru dan kebingungan tentang cara menilai siswa selama belajar di rumah serta mememberikan pemahaman tentang pentingnya keterlibatan orang tua. Hasilnya, skema penilaian yang dimanipulasi telah diperkenalkan dalam penelitian ini. Ini dapat digunakan tidak hanya selama pandemi Covid-19, tetapi juga dalam program pendidikan normal. Di sisi lain, komunikasi antara orang tua dan sekolah harus terus dijaga untuk mendapatkan hasil yang terbaik dari prestasi siswa.
\end{abstract}

Keyword: Pembelajaran Jarak Jauh, Keterlibatan Orang Tua, Skema Penilaian

\begin{abstract}
This study is aimed at providing an assessment scheme during learning at home by involving parents. Teachers as well as parents' role in an intensive communication were emphasized under collaboration to help each other. The method used in this research was argumentative literature review on standard document of Panduan Penilaian oleh Pendidik dan Satuan Pendidikan (Kemendikbud, 2017). The purpose of this research is focusing on reducing teachers' workload and confusion on how to assess students during learning at home. On the other side, it is to give an understanding of the importance of parental involvement. As a result, a new manipulated assessment scheme had been introduced in this research. It could be used not only during the Covid-19 pandemic but in a normal program of education. Lastly, the communication between parents and school should be well maintained in order to get the best result of students' achievements as well.
\end{abstract}

Keyword: Learning at Home, Parental Involvement, Assessment Scheme 


\section{INTRODUCTION}

The Covid-19 pandemic that is now outbreaking is very troubling for many sectors of life. One of them is penetrated into the education sector. About $91 \%$ of the students' population has been affected by the school closing due to this pandemic (Kemendikbud, 2020). Studying at home or home learning is a choice taken by Indonesia, under the Minister of Education and Culture. It is also done in almost all countries affected by this COVID-19 outbreak. Instead of being successful, the learning program from home precisely encountered very many obstacles in terms of the sustainability of the education system. The teacher feels confused about the teaching method to be used. Learning through online platforms is new for some teachers. Communication technology is one of the keys to success learning from home which is being implemented (Sapungan \& Sapungan. 2014). However, teachers' beliefs and thought about assessment will influence conducting, the way of implementing, interpreting, and practicing it (Brown \& Gao, 2015). As assessment holds an important role in education, participating in an assessment course hold by the authority is important to do to increase teachers' conception of assessment (Levy-Vered \& Abu-Alhija, 2018).

Learning from home is the program of learning conducted by many countries to stop the Covid19 outbreak. It has been implemented in many countries several months ago as well as Indonesia. It is also predicted to be an unpredicted prediction of the time. Nobody is able to predict when is the end of this pandemic precisely. With the utmost change of the learning system, the students' assessment system also experienced many changes. Not a few teachers are still getting confused about how to collect the grades from students. However, fair assessment requires the same administrative things, interpretation, way giving the score, the same content, and analysis wherever and whenever it is conducted (Tierney, 2014, 2016).

Assessment during remote studying or studying from home yields some technical questions for many teachers. As assessment is one of several basic components in the formation of the curriculum, it needs to be careful in defining it (Art-In, 2018). It is something that must be done at the end of each period, but sometimes during the classroom activity (Qu and Zhang, 2013). There are some purposes of the implementation of the assessment with various kinds. One of those is to cover up and know students' improvement after getting involved in a learning process for a certain period (Trumbull and Lash, 2013). It is also to know the result of how far students' understanding of the given study is (Stufflebeam, 1973). However, there are many ways to assess students learning progress. One of the strongly suggested methods is authentic assessment as it has been strongly recommended. The most important thing is fair assessment in every situation (Murillo \& Hidalgo, 2020).

In general, assessment is divided into two parts, formative assessment, and summative assessment. Formative assessment is an assessment process conducted to determine learners' development in the middle of the learning process (Black and William, 2009). Usually, this assessment is done separately to see the attitudes and behavior of students change at a certain time to measure whether it is as expected or not ( $\mathrm{Qu}$ and Zhang, 2013). On the contrary, summative assessment is an assessment method that is taken to find out developments over a certain period in a number of ways. However, three domains of learning that should be assessed should be clearly conducted wherever and whichever it is. Those are Attitude, Knowledge, and Skills (Kemendikbud, 2017).

Parental involvement becomes one important key in assessing and improving students' achievements. However, some locals in Indonesia show a low level of parental involvement. Syamsudduha (2017), whose research was conducted in Makasar, illustrated a low level of parental involvement. Specifically, they found the differences in parent's perception of their child's education in urban and rural areas. Similarly, Yulianti, Denessen \& Mienke (2019) showed the same result of parental involvement which is categorized as low level. Its differences are related to socioeconomic. Some welleducated parents even say that they have a lack of power and opportunity to be active at school. Thus, 
this becomes a problem in remote learning. However, this pandemic situation demands parents to be involved more in their children's education.

Therefore, to address this problem, the authors present an improved assessment flow that teachers may use in the learning process during the COVID-19 pandemic. It is because the researcher did not find an assessment scheme during this pandemic era that is suitable to the context of learning from home. Thus, it remains some difficulties for teachers. Then, it will clearly become the novelty of this research. However, this situation should not stop doing fair assessment toward students. Justice with equality and equity are the concepts of fair assessment (Murillo \& Hidalgo, 2020). So, this research is intended to give new ide of an assessment scheme for teachers during remote learning implementation. It is needed and such a must to help teachers running the learning process easier by involving family to be part of the students' achievement improvement (Ceka \& Murati, 2016).

\section{METHOD}

This study could be classified into an argumentative literature review which draws back the white thread from the importance of assessment by involving parents. This research was conducted by gathering data from various sources as known as qualitative data (Creswell, 2012). Some data related to parental involvement were adopted. This research analyzed the assessment document from the Minister of Education and Culture of Indonesia called Panduan Penilaian oleh Pendidik dan Satuan Pendidikan (Kemendikbud, 2017). It is assessment guidance for educators and units of education under the Minister of Education and Culture of Indonesia. Reading and making notes were used in observing and collecting the data to be then modified to adjust to the current situation.

The validity and reliability of this research were done through the perseverance of observation to Panduan Penilaian oleh Pendidik dan Satuan Pendidikan document from Kemendikbud. Then, rereading and re-checking, as well as peer-checking of the document. The concepts were popularly known as triangulation. It's done to put together an assessment map for teachers to further reduce the workload and confusion during the COVID-19 pandemic and also help teachers building a conceptual assessment. It is all supported by related research and other conceptual standards sources to be concluded in an idea of designing a simple road map of educational assessment at home by involving parents and teachers. The second step is analyzing the related topic based on Kurikulum 2013 (K-13) under the instruction of the Ministry of Education and Culture of Indonesia.

\section{DISCUSSION}

\section{Assessment in term of formative and summative assessment}

Various definitions of assessment. Cronbach (1970) and Stufflebeam (1971) stated that assessment in a curriculum is a process of gathering data and information. Specifically, Kemendikbud (2017) stated assessment as the data collecting and gathering to measure students' achievement and learning outcome. It is clearly stated under some legal foundation of mandatory of the Minister of Education of Indonesia.

Technically, assessment is divided into formative and summative assessments. Firstly, there is no consistent definition of what formative assessment is (Wiliam, 1998). Some define that formative assessment is done during a classroom activity. It can be conducted by teachers to measure some points from their students. While, formative assessment is defined as the procedures of making decisions of students' achievement by teachers, their peers, other students in order to make the next step decision to be better (Black and William, 2009). It clearly defines that the assessment can be done not only by the teachers but also by students' self-assessment or small group assessment. Those contexts will define kinds of the peers of the students. This situation will get the parents and family as their peers automatically. It can not be denied that parents should be involved when students learning from home. On the other hand, it also lies two main points from the formative assessment. 
Ramaprasad (1983) and Sadler (1989) stated that two main core of the formative assessment: 1) the perception of learner about their own gap between expectations and reached goal, 2) the action that students should take to close the gaps so that they can reach the desired goal. Both are about self assessment. Students can take their own role and ownership in learning when they know the objectives to be reached not to get final score (Trumbull and Lash, 2013).

Furthermore, formative assessment is not only difficult to do during learning from home, but also very difficult to apply during normal class as usual. Some teachers even don't have a good understanding of formative assessment (Dixon and Williams, 2001). There are many ways to do formative assessment. Rubric is one of the best ways that can be used to do formative assessment. But, to determine how this formative assessment depends on planning (Purpura, 2016). If so, during this crucial condition, involving parents in the process of assessing students is the best plan to have by the teachers. Things to assess will be defined by the three domains of learning. The way to assess will depend on teachers' plan (Purpura, 2016). While rubric is an assessment form that has several criteria that will be used for standards that include levels that match the description (Brookhart, 2013). Rubrics have similarities with rating scales. The difference only lies in the level of description. In the rating scale, there is no description level as in the rubric (Jonsson and Svingby, 2007). Besides, the Rating scale, note-taking, and checklist are other kinds of assessments. Shortly belongs to systematic assessment.

Differently, summative assessment is conducted after the period of teaching in the majority (Anthony J. \& Susan M, 2005). On the other definition, Bloom et al (1971) stated summative assessment as the data collecting done to assess the course program and whole educational process to classify and evaluate progress after a teaching process at the peak of a certain period. In short, it is used to identify what learners have learned and then conduct the judgment and summary of the progress (Luo Shaoqian, 2003). The summative assessment purpose is to know the final result of the students learning process. It is used to know what students got after classroom activity (Qu and Zhang, 2013). Some familiar formative assessments have been introduced in many countries. One of them that is commonly used is multiple choice. It is just a type of summative assessment in form of technical practice. It has some strengths and weaknesses. Teachers get easy to find and correct students' work is one of the advantages seen from the teachers' side (Qu and Zhang, 2013).

Regarding the importance of conducting a fair assessment in this situation, parents should also need to be actively involved. However, parents' understanding may differ oftentimes; It may be influenced by the level of education (Ceka \& Murati, 2016). Therefore, teachers need to make sure that parents will have a well understanding of formative and summative assessment. Practically, to enhance parents' understanding of the importance of formative and summative assessment.

\section{What to assess?}

Three main domains such as Attitude, Knowledge, and Skills are being the objectives that should be assessed (see Figure 1). Kemedikbud (2017) officially set the regulation of the assessment done by educators. As well as other general conceptions, Attitude Assessment, Knowledge Assessment, and Skills Assessment become the major domain to be assessed. The clear figure of the domain to assess can be seen as follow:

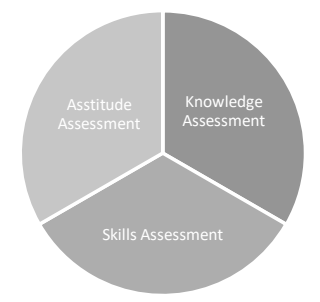

Figure 1: Basic domains to be assessed in education. 
Assessment that should be done by teachers has at least those three domains as stated above. Attitude assessment is done toward knowing the attitude change in daily life. It should cover either inside or outside of the classroom (James, 2015). However, Tyler (1949) proposed attitude as one of the mandatories of the whole education system (Art-in, 2018). Similarly, the current national curriculum of Indonesia emphasized the importance of students' attitude development. Therefore, a fair assessment of attitude wherever the learning process is conducted is a must. Secondly, Knowledge assessment is a process of gathering any data to measure the learning result and cognitive process such as to remember, to understand, to apply, to analyze, to evaluate, and to create (Anderson \& Krathwohl, 2001). This domain has equal importance in learning like attitude. Knowledge is closely related to attitude as a process of thinking. Lastly, skills assessment as known as a practice assessment is the process of measuring students' ability in applying the learning process during separated time toward the competence indicators. Skills assessment should cover both thinking and do/ practicing skills (Kemendikbud, 2017). However, some of the skills that students need to master has been covered in 21 st-century skills. It proves the importance of skill assessment either inside or outside of the classroom.

Thus, those three domains of learning can be assessed in various ways based on the needs and condition. Each domain has a different way of assessing it. Unfortunately, Kemendikbud (2017) proposed all assessment activities covering those three domains belong to the teachers' duty. Teachers must cover all assessments in those three domains. However, the current condition of learning may drive educators to be creative in assessing their students. As learning from home is now implemented under the official decision of the Minister of Education and Culture, the assessment scheme should be flexibly modified by involving parents.

\section{Parents' Roles in Assessment}

Normally, in a classroom, teachers conduct assessments and decide students' next step on achievement before reporting to parents. Here in this unpredictable situation, it must be changed. Center for Child Well-Being in Sapungan \& Sapungan (2014) stated parents' role in education can not be avoided. It has a special support system that should not be underestimated regarding safe feeling. Family and parents need to be involved permanently in education to get the best result of students' improvement. However, parents' level of education determines and affects the success of students' development, it regards the way and knowledge over the children educational treatment (Ceka \& Murati, 2016). School and parents should have a strong connection with each other. It affects students' view about an integral part of the school and family to be one another. Students intend to have families to be more knowledgable between school and home (Mapp. K \& Henderson A. 2002). But, those intention is not as easy hope. Some barriers will be found in facing the communication between school and home. National Center for School Engagement stated in Sapungan \& Sapungan (2014) that four elements in parental involvement in school that often occur. Firstly, the attitudes of the staff are sometimes the prominent barriers that should be overcome. The staff doesn't feel comfortable doing any issue in front of the family. Secondly, logistics in some countries sometimes become other barriers. The parents can not come to any meeting provided by school for logistics reasons. Third, the system doesn't cover and involve parents to be part of the formal education system. Last, the lack of skill is the most dangerous problem between parents and children improvement.

Parental involvement becomes one important key in assessing and improving students' achievements. However, some locals in Indonesia show a low level of parental involvement. Syamsudduha (2017) whose research was conducted in Makasar, illustrated a low level of parental involvement. Similarly, Yulianti, et al. (2019) stated the same result in their research. Specifically, they found the differences in parent's perception of their child's education in the urban and rural areas. Its differences are related to socioeconomic. Some well-educated parents even say that they have a lack of power and opportunity to be active at school. Thus, this becomes a problem in remote learning. However, this pandemic situation demands parents' involvement more in their children's education. 
Parents and schools are required to have collaborative works to gain the expected good result on student's achievements.

Joyce Epstain, Center on School, Family and Community Partnership in Sapungan \& Sapungan (2014) stated some tips to use in developing family's quality to participate in raising and controlling students' achievement. Those tips are:

a) Parenting: school should support parents'skill by promoting some parenting program.

b) Communication: It should be two ways communication between school and home.

c) Volunteering: Parents' assistance and support are quite needed. In line with the two says communication.

d) Learning at home: School holds parents in understanding the educational process and their roles in supporting students' achievement.

e) School decision making and Advocacy: School should involve parents voice in making decision that is affected to their children's education.

f) Community cooperation: It chould involve some community in supporting the communication and process of students' improvement (Sapungan \& Sapungan (2014)

Learning at home becomes one of some tips in overcoming the problem of learning. However, this unpredictable situation can not be blamed as an ineffective process. Students should get a fair assessment either inside or outside of the classroom fairly (Murillo \& Hidalgo, 2020). By involving parents, the learning and assessment of students' achievement hoped to get easier ways of process. The partnership between teachers and parents has a significant influence on sharing information about students' improvement (Putri et al, 2018). That is in line with Olsen (2010) who has proven that the tips mentioned above affect the positive result in improving students' achievements. By using technology platforms, those all can be done.

\section{Assessment Scheme during COVID-19 Pandemic}

Classroom learning is normal for teachers. Thus, Kemendikbud (2017) under the core curriculum of Indonesia, Kurikulum 2013 (K-13), has set the assessment scheme of those three domains that should be assessed by the teachers. All assessments should be done by the teachers. It has been implemented since the teachers are known as the learning and teaching first executors. It can be seen from this figured out table below:

Table 1: Classroom assessment scheme by teachers (Kemendikbud, 2017)

\begin{tabular}{llll}
\hline No & Method & \multicolumn{1}{c}{ Executor } & Note \\
\hline $\mathbf{1}$ & & & Attitude \\
\hline & Observation & $\begin{array}{l}\text { Homeroom teacher/ } \\
\text { Subject teacher }\end{array}$ & Observation form/ Checklist/ Rubric/ Rating Scale \\
\hline & $\begin{array}{l}\text { Peer- } \\
\text { assessment }\end{array}$ & Students & Checklist/ Rubric/ Rating Scale \\
\hline & $\begin{array}{l}\text { Self- } \\
\text { assessment }\end{array}$ & Students & Checklist/ Rubric/ Rating Scale \\
\hline $\mathbf{2}$ & & Knowledge \\
\hline & Written test & Teachers & Essay/ Multiple choices based on Basic Competence \\
\hline & $\begin{array}{l}\text { Interview/ } \\
\text { spoken }\end{array}$ & Teachers & Interview form and questions \\
\hline & Assignment & Teachers & Before and after learning process \\
\hline $\mathbf{3}$ & & & Skills \\
\hline & Practice & Teachers & Learning achievement assessmet of process \\
\hline
\end{tabular}




\begin{tabular}{lll}
\hline Product & Teachers & Learning achievement assessmet of product \\
\hline Project & Teachers & $\begin{array}{l}\text { Learning achievement assessmet of learning } \\
\text { application }\end{array}$ \\
\hline Portfolio & Teachers & The end of semester \\
\hline
\end{tabular}

Table 1 shows us that all assessment process should be done by the teachers. Students may be included in this assessment process, but teachers may control all activities in the classroom. However, this kind of assessment will not be effective during learning from home. It is impossible for teachers to do an assessment that requires students to be at school. Therefore, some improved assessment schemes should be created in order to be adaptable to the current situation. However, this assessment scheme proposed by Kemendikbud (2017) has not included parents in its process. All of the assessment activity is normally conducted by the teachers, subject, or homeroom teachers.

Therefore, it yields some difficulties to implement during remote learning, in which parents should be directly included. Involving family in this situation is quite needed to gain the best result of students' achievement (Ceka \& Murati, 2016). However, it is a need to change the scheme. Further revision on its concept might be needed for the sake of the clearance of the assessment flowchart. However, some parts of the assessment executors may include parents. It is to make it possible to do as the learning process is being held at home. A teacher may only control the activity remotely. Then, the scheme of assessment will be different as follow:

Table 2: Collaborative Assessment Scheme between teachers and parents

\begin{tabular}{|c|c|c|c|}
\hline No & Method & Executor & Note \\
\hline \multirow[t]{4}{*}{1} & & & Attitude \\
\hline & Observation & Parents & Observation form/ Checklist/ Rubric/ Rating Scale \\
\hline & Peer-assessment & Students & Checklist/ Rubric/ Rating Scale \\
\hline & Self-assessment & Students & Checklist/ Rubric/ Rating Scale \\
\hline \multirow[t]{4}{*}{2} & & & Knowledge \\
\hline & Written test & Teachers & Essay/ Multiple choices based on Basic Competence \\
\hline & Interview/ spoken & Teachers & Interview form and questions \\
\hline & Assignment & Teachers & Before and after learning process \\
\hline 3 & & & Skills \\
\hline & Practice & Parents & Learning achievement assessmet of process \\
\hline & Product & Parents & Learning achievement assessmet of product \\
\hline & Project & Parents & Learning achievement assessmet of learning application \\
\hline & Portfolio & Teachers & The end of semester \\
\hline
\end{tabular}

In this assessment scheme, teachers must actively be involved in the process of assessing those three domains. It is impossible for teachers to reach out to all students at home. Therefore, collaborative activity between teachers and parents must be increased. Teachers may reach students' activities at home, but it will not be effective for sure. However, parents must take responsibility for the process of teaching and learn as well as an assessment activity. Furthermore, communications between teachers and parents seem to be the primary key to this remote learning success as said by Joyce Epstain concept. The place of schools, either in rural or urban don't mean barriers to effective communication between 
school and parents (Fagbeminiyi, 2011). However, some of the related forms to assess students during learning from home may be furtherly seen through the appendixes.

\section{CONCLUSION}

The discussion part of this research may give us the conclusion that parental involvement in every situation of learning is consistently needed. On the other hand, as the assessment is one of the prominent elements in a curriculum, the improved assessment scheme (see Table 2) might give a new concept of assessment that teachers may implement during the current situation due to the COVID-19 pandemic. Learning from home has been being implemented in some countries, including Indonesia. However, parental involvement is crucially needed during the learning process as well as an assessment activity. However, teachers may not leave parents to it independently. Teachers' guidance is much needed in order to control the assessment activity to keep on the standards.

Some useful benefits of parental involvement and networking between family and school have proven themselves as the best thing to improve students' achievements. It was proven by some previous researchers. However, the current situation due to the Covid-19 pandemic imposes schools and families to have that good partnership or working. Assessment schemes related to the task of parents as part of students' assessment can not be avoided. This research draws a different view of the usual scheme in which parents are more involved in the educational program of the school. This research also offers some tips on the experimental networking that school and family should do. Intensive communication is the key to gain students' improvement and free-learning feeling of students. On the other hand, some communication barriers between family and school can be solved through some tips provided. However, some research stated that Indonesian parents are still on a low level of involvement in childs's education at school. To sum up, by conducting the scheme of assessment provided in this research, teachers may not get any confusion on conducting fair assessment wherever and whenever it is.

\section{REFERENCES}

Asesmen revisi Taksonomi Pendidikan Bloom. Yogyakarta: Pustaka Pelajar.

Anthony J. Nitko., Susan M. Brookhart. (2005). Education Assessment of Students. New Jersey: Person Education Ltd

Art-In, Sitthipon. (2018). Curriculum Development. Khon Kaen: Khon Kaen University Press

Black, P., William D. (2009). Developing the Theory of Summative Assessment. Educational Assessment Evaluation and Accountability, 2(1) doi.org/10.4135/9781446250808.n13

Bloom, B.S., Hastings, J, T., Madaus, G. F. (1971). Handbook on Formative and Summative Evaluation of Student Learning. New York: MacGraw-Hill.

Brookhart, Susan M. (2013). How to Create and Use Rubrics for Formative Assessment and Grading. Alexandria: ASCD.

Brown, G. T.L., Gao, L. B. (2015) Chinese Teachers' Conceptions of Assessment for and of Learning: Six Competing and Complementary Purposes. Cogent Education, 2 (1),1-19. doi.org/10.1080/2331186X.2014.993836

Ceka, Ardita., Muranti, Rabije. (2016) The Role of Parents in Education of Children. Jornal of Education and Practice, 7 (05, 61-64

Creswell, John W. (2012). Educational Research: Planning, Conducting and Evaluating Quantitative and Qualitative Research (4 ${ }^{\text {th }}$ Edition). Boston: Pearson

Cronbach, Lee J. (1970). Essential of Psychological Testing $3^{\text {rd }}$ Ed. New York: Harper Row

Dixon, H., Williams, R. (2001). Teachers Understanding of Formative Assessment. New Zaeland Annual Review of Education, 12, 95-110. 
Epstein, J.L. (2009) School, family, and community partnerships. Corwin Press: Thousand Oaks, California

Fagbeminiyi, Fasina F. (2011). Role of Parents in Early Childhood Education: A Case Study of Ekeja, Lagos State, Nigeria. Global Journal of Human Social Science, 11 (2), $42-51$

James, Mary. (2015). Educational Assessment: Overview. United Kingdom: McGaw

Jonsson, Anders, and Gunilla Svingby. 2007. The Use of Scoring Rubrics: Reliability, Validity and Educational Consequences. Educational Research Review 2 (2): 130-144. doi: 10.1016/j.edurev.2007.05.002

Kemendikbud. (2017). Panduan Penilaian oleh Pendidik dan Satuan Pendidikan. Jakarta: Kementerian Pendidikan dan Kebudayaan Direktorat Jenderal Pendidikan Dasar dan Menengah Direktorat Pembinaan Sekolah Menengah Pertama

Kemendikbud. (2020). Panduan Pembelajaran Jarak Jauh: Bagi Guru Selama Sekolah Tutup dan Pandemi Covid-19 dengan Semangat Merdeka Belajar. Jakarta: Direktorat Jendral Guru dan Tenaga Kependidikan Kementrian Pendidikan dan Kebudayaan

Levy-Vered, Adi., Abu-Alhija, Fadia Naser. (2018). The power of a basic assessment courses in changing preservice teachers' conceptions of assessment. Studies in Educational Evaluation. 59. 84-93. doi.org/10.1016/j.stueduc.2018.04.003

Luo Shaoqian. (2003). The Research of English Classroom Teaching. Beijing: Foreign Language Teaching and Research Press.

Mapp, K., \& Henderson, A. (2002). A New Wave of Evidence, The Impact of School, Family, and Community Connections on Student Achievement. Texas: SEDL

Murillo, Javier R., Hidalgo, Nina. (2020). Fair Student Assessment: A Phenomenographic Study on Teachers' Conception. Studies in Educational Evaluation, 65, 1-10. doi.org/10.1016/j.stueduc.2020.100860

Moleong, L. J., (1988). Metode Penelitian Kualitatif. Depdikbud, Jakarta

Nicol, D.J. and Macfarlane-Dick, D. (2006) Formative assessment and self-regulated learning: a model and seven principles of good feedback practice. Studies in Higher Education 31(2): 199-218 . doi.org/10.1080/03075070600572090

Trumbull, E., \& Lash, A. (2013). Understanding formative assessment: Insights from learning theory and measurement theory. San Francisco: WestEd.

Olsen, G. (2010). The benefits of parent involvement: What research has to say. Retrieved June 1, 2020, from http://teaching.about.com/od/Jrteachingv ocabulary/g/Parental-Involvement.htm

Purpura, J. E. (2016). Second and foreign language assessment. The Modern Language Journal, 100(S1), 190-208. doi.org/10.1111/modl.12308

Putri, Lili D., Hatimah, Ihat., Kamil, Mustofa. (2018). Family Partnership Strategy with an Early Childhood Education (PAUD) Institution: A Case Study on PAUD Bianglala Bandung. Non Formal Education International Conference (NFEIC 2018), Bandung, 293, 56-59.

Qu, Wenjie \& Zhang Chungling. (2013). The Analysis of Summative Assessment and Formative Assessment and Their Roles in College English Assessment System. Journal of Language Teaching Research, V (4), 335-339. doi:1 0.4304/jltr.4.2.335-339

Ramaprashad, Arkalgud (1983). On The Definition od Feedback. Behavioral Science, 28, 4. 13. doi.org/10.1002/bs.3830280103

Sapungan, Gina. M., Sapungan, Ronel. M. (2014). Parental Involvement in Childs' Education: Importance, Barriers and Benefits. Asian Journal of Management Science and Education, 3 (2), $42-48$

Stufflebeam, Daniel L. (1973). Educational Evaluation and Decision Making, in Education Evaluation: Theory and Practice. California: Wadsworth Publishing Company 
Syamsudduha, St., Ginanto, Dion. (2017). Parental Involvement in Indonesia: A Study on Two Public Shools in Makasar. Education and Humanities Research (ASSEHR). 66, 407-411

Tierney, R. D. (2014). Fairness as a Multifaceted Quality in Classroom Assessment. Studies in Educational Evaluation, 43, 55-69. doi.org/10.1016/j.stueduc.2013.12.003.

Tierney, R. D. (2016). Fairness in educational assessment. In M. A. Peters (Ed.). Encyclopedia of Educational Philosophy and Theory (pp. 1-6). Singapore: Springer Science. doi.org/10.1007/978-981-287-532-7_400-1.

Yulianti, Kartika., Denessen Eddie., Droop, Mienke. (2019). Indonesian Parents' Involvement in Their Children Education: A Study in Elementary School in Urban and Rural Java, Indonesia. School Community Journal, 29 (1), 253-278. 